\title{
The impact of using concordancer on EFL learners' reading comprehension
}

\author{
Ashtiani, Parya \\ University of Guilan, Iran (parya.ashtiani@gmail.com) \\ Tahriri, Abdorreza $\triangle$ \\ University of Guilan, Iran (atahriri@gmail.com)
}

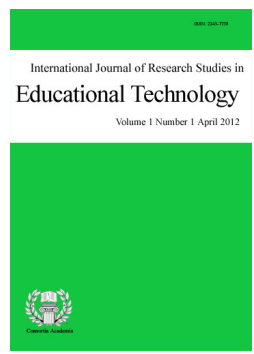

ISSN: $2243-7738$ Online ISSN: 2243-7746

Received: 7 January 2013

\begin{abstract}
This study investigates the effectiveness of using computer-aided program, concordancer, in an extensive reading course. Nine female EFL learners participated in the study which utilized a repeated measure design. During the experiment, each day the students of experimental phase were assigned one story to read at home. Control group was instructed traditionally. For the control group, the instruction heavily relied on annotations, the texts and dictionaries without specific teaching aids and at the end of the class, the participating EFL learners were engaged in a twenty-minute discussion. The data were collected by pretest (a placement test), progress tests and posttest (comprehension test). A non-parametric test, the Wilcoxon Signed Rank Sum was employed to analyze the data. The results showed that utilizing concordancer, AntConc; for text analysis, experimental group improved significantly better than the control group in terms of reading comprehension.
\end{abstract}

Keywords: computer-assisted instruction; concordancer; reading comprehension; EFL 


\section{The impact of using concordancer on EFL learners' reading comprehension}

\section{Introduction}

In the EFL context, reading is very often the only source of comprehensible and meaningful linguistic input that helps unconscious acquisition of the language (Krashen, 1981). Therefore, through decoding sounds, words, and sentences, reading requires upper-level thinking skills and social awareness (Burns, 2003). While reading, there is a large cognitive load on the reader, namely, decoding the text and blending the textual information into his knowledge base. In order to be a critical reader, one needs to go well beyond the literacy of reading and the level of words and surface meaning to realize the writer's implications or messages and incorporate the background knowledge and experiences with the meaning of the printed page. In fact, learning to read improves the thinking ability, and learning to think facilitates the reading comprehension.

On one hand, research has proved that proficient readers actively use a set of strategic processes such as previewing, setting goals, predicting, asking questions, monitoring understanding, and making connections for creating meaning from text (Block \& Pressley, 2002). And on the other hand, studies have also focused on how to engage learners in reading an abundance of texts. Moreover, researches have revealed that extensive reading is the key to achieving higher reading proficiency (Krashen, 1993; Green \& Oxford, 1995). Furthermore, in order to encourage learners to read materials, explore features of the L2, take control of the corpora, learn independently and reduce reading difficulty resulting from such an abundance of linguistic resources, one of the most recent promising innovations in computer-assisted language learning (CALL) is the use of concordancers (Cobb, 1997; Steven, 1991). It is a sophisticated computer retrieval program with abundant pieces of information in the form of computer language corpora accessible to encourage data-driven inductive learning. In fact, through concordancers, EFL learners can have easier access to wider applications and test their hypotheses on a particular linguistic usage in real texts.

Research has shown that readers tend to face more difficulty in inferring the meaning of new words from context when they read authentic texts (Laufer \& Sim, 1985; Haynes, 1983; Huckin, Hayne, \& Coday, 1991).In addition, if readers require further contextualization to construct the meaning of a word, they can easily click a concordancer for wider contexts where the keyword occurs. All in all, concordancers make available the real language in use in different texts, foster the EFL learners' analytical capacities, increase the explicit knowledge and usage of the language, facilitate critical language awareness, and accelerate the development of learner autonomy, which leads to data driven learning (DDL).

\subsection{Statement of the problem}

While reading, learners should be informed about the gap between the writer and the reader. In order to bridge the gap, learners need the necessary skills or tools to be able to cope with comprehending a given text. In the light of technology, integrating computers as tools of language teaching has adorned the classrooms and sought to facilitate language learning. These instructional tools can be incorporated into teaching practice to make instruction feasible and appropriate as they become available. Thanks to technology, nowadays, teachers have access to the Internet and available computer-aided teaching facilities; therefore, they have the opportunity to implement them in the classrooms and serve the instructional goals and frameworks in a more effective way so that they might be able to support and facilitate the development of reading skill. Among different tools and teaching aids, as Conrad and Rautenhaus (1994) stated, a web concordance is a tool to search for words in different contexts, and analyze corpora that feature electronically stored written texts or transcriptions of spoken language on different topics.

By using concordancers, learners are involved in exploring and observing the target language. Consequently, 
the capability of contextual inference could be substantially enhanced by providing multiple contexts for a given word (Cobb, 1997; 1999). Therefore, learners are encouraged to work as linguistic researchers, hypothesizing and testing lexical or grammatical usage patterns (Johns, 1991a, 1991b).This study, therefore, tried to integrate computer-aided program, concondancer, in an extensive reading class in order to investigate the impact of analyzing the corpora through concordancers on EFL learners' reading skill.

\subsection{Objectives of the study}

Much research has been conducted in the latter part of the twentieth century regarding how students learn best (Johnson, Johnson, \& Stanne, 2000). Among the tools and techniques of corpus linguistics which have been utilized in foreign language teaching and learning, concordancer is the most popular learning tools. Through this, learners can efficiently uncover hidden linguistic patterns in large amount of data and answer their own questions about the foreign language. The present study focused on utilizing concordancers as a tool to develop reading skill and data-driven learning (DDL) on the basis of extensive reading in order to examine whether or not more efficient comprehension can be achieved in language classroom. In other words, the present study intended to investigate the impact of computer-aided program, through using concordancer, on the improvement of EFL learners' reading skill based on extensive reading materials.

\subsection{Significance of the study}

Few studies have been carried out to examine the integration of concordancers within language instruction in an EFL context. Computer-assisted language learning can provide a learning environment that promotes positive self-guided learning among learners. Thus, the present study gains significance as the results can shed more light on the effect of computer-aided instruction, concordancer, on promoting EFL learners' reading comprehension in an extensive reading course. The finding of the study can be of use to syllabus designers and EFL instructors. On one hand, syllabus designers can benefit from the findings of the study and develop a better understanding of the role of CALL softwares in language instruction. On the other hand, teachers can utilize computers in the classrooms to facilitate the teaching process and possibly motivate students further.

\subsection{Research question}

The present study intended to seek answer to the following question: Does computer-assisted extensive reading instruction have any impact on female EFL learners' reading comprehension?

\section{Review of Literature}

With the advent of technology and its consequent impact on stylistic literary studies, the quality of teaching and learning in language classrooms has been enhanced. An attempt has been made to integrate computers, the Internet and computer-aided program as tools in language classrooms to facilitate teaching and learning. The most important goal of modern pedagogy is to help learners go beyond the lower order cognitive skills to the higher order thinking ones, including application, analysis, synthesis, and evaluation (Bloom et al.,1956). These skills are necessary for learners to analyze, evaluate, synthesize, use critical insight, be creative, work collaboratively, solve problems, and direct their own learning (Romiszowski, 1996). In order to obtain mastery of these skills, teachers need to provide learning environments that are learner-centered, authentic, problem-based and collaborative.

With increasing number of research, the beneficial effects of (online) computer-assisted programs on language learning have emerged. They have intended to support the pedagogical concerns in the classrooms. Among the modern teaching aids, concordancers characterized as computer-based programs became available in the 1980s and a number of studies have been conducted to provide empirical evidence to the effectiveness of corpora concordancing in language classrooms (Hadley, 2000; Ilse, 1991; Lee \& Liou, 2003; Someya, 2000 ; St. John, 2001). Concordancers provide a list of frequency occurrences in a pre-selected corpus and involve 
displaying the defined items within the current context. They search for occurrences of a given word, part of a word, combination of words, a punctuation mark, affix, or a phrase or structure within a given text corpus to show its immediate context (Granger, 1998; Biber, Conrad, \& Reppen, 1998).

Through this, learners can develop their ability to observe, to speculate and to identify patterns in the target language (Johns, 1988). In addition, the output of concordancer searches and presents learners with authentic, actual choices that language users make and allows them to explore and discover ordinary patterns of word or sentence usage in various styles. Therefore, the capability of contextual inference can be substantially enhanced by providing multiple contexts for a given word with the aid of a computer system (Cobb, 1997, 1999). As a result, concordances have been used for a range of purposes. By using concordancers, the learners can explore features of target language independently, including rules of grammar, the usage in different context, and lexical attributes. This, consequently, leads to data-driven learning (DDL) (e.g. Johns, 1994). By this pedagogical approach, learners are research workers, who discover and analyze rules and patterns embedded in the data rather than implementing rule application exercises or following a spoon feeding approach.

Prior studies have shown that a DDL approach creates a learner-centered learning atmosphere in which learners are involved in exploratory concordance-based tasks to expand their language experience (Biber, Conrad, \& Reppen, 1998). Furthermore, they can discover the underlying language patterns on their own, and thus they become active participants in the learning process (Brown, 2001; Johns, 1997; Sun, 1999). Therefore, the data-driven approach using concordance software stimulates the learners' analytical capacities, improves their explicit knowledge of target language, advances critical language awareness, and supports the development of learner autonomy. Moreover, learners themselves also show positive reactions to DDL and using concordancer due to their growing consciousness of descriptive rather than prescriptive language (Chambers, 2005; Yeh, Liou, \& Li, 2007).

Several studies have been carried out to evaluate the potential of using concordancer and explore approaches to integrate concordancing tools into language learning and teaching (Chen, 2000; Cobb, 1997; Conrad, 1999; Flowerdew, 1993; Turnbull \& Burston, 1998). In Todd's (2001) study, a class of college students consulted a web-based corpus to help with their self-corrections of lexical errors. The results showed that these students were able to induce valid patterns from their self-selected concordances and to make valid self-corrections of their errors. Gabel (2001) conducted a research in which the focus was on another possibility of applying concordancers, namely, a comparative study aiming at insights into the learners' interlanguage (IL) and examined the over-indulgence and under-representation of linguistic features in the language use of advanced German EFL students. It was concluded that learners benefited because they tried to bridge the gap between their own performance and that of native speakers.

In addition, in Malaysia, the study carried out by Nuraihan and Husin (2004) indicated the potential of a literary text, Othello, and a concordancer in developing and enhancing critical thinking ability and the findings revealed that there is a significant difference between the experimental and control groups in their critical thinking ability. Sun (2003) conducted a study that endeavored to implement a reading program, Extensive Reading Online (ERO), featuring specific needs for EFL learners in Taiwan. He utilized concordancer, stage-by-stage reading strategy training, and text annotation functions. The results indicated that students held a positive attitude toward the reading system. Again, in the same year, Sun worked on a case study by three Taiwanese college students which conducted the learning process in the concordancer setting. During undertaking a proofreading activity, a web-based concordancer assisted the participants. Four factors evolved in the results and learners' learning process: (1) prior knowledge, (2) cognitive skills, (3) teacher intervention, and (4) concordancer skills.

Concordancer is also beneficial in the acquisition of vocabulary (Cobb, 1997; Zahar et al., 2001). In addition, the second language vocabulary knowledge includes chunks, such as collocations or idioms (Nation, 2001). Much of the research on concordancers has focused on grammar and collocation learning. It is believed that 
collocational knowledge is difficult to acquire for language learners (Church et al., 1991) and it is especially effective for sentence generation (Smadja \& McKeown, 1990). Sun and Wang (2003), with a class of eleventh grade students in Taiwan, examined the effect of concordancing on learning grammatical collocations and they found the inductive group significantly outperformed deductive group in the proofreading task. Similarly, Lee and Liou (2003) probed into the effect of students as corpus researchers by assessing and comparing the lexical performance of students and the results showed that concordancer searching was beneficial to students who employed inductive learning strategies. In the field of collocation, in 2005, Chan and Liou carried out a study to explore the impact of using five web-based practice units on English verb-noun collocations with the aid of a web-based Chinese-English bilingual concordancer. Results indicated that learners improved significantly after the online practice at once but regressed later. Moreover, the online instructional units with utilizing the concordancer were acceptable to most learners.

In the context of ESL learners, Horst et al. (2005) blended the use of a concordance, a dictionary, a cloze-builder, a hypertext, and a database with interactive self-quizzing features in several academic English courses and evaluated the effects of the tools and activities on 150 students. The findings evidenced the learning gains provided support for vocabulary learning. Webb and Kagimoto (2009) examined the effects of three factors (the number of collocates per node word, the position of the node word, synonymy) on learning collocations. The results revealed that more collocations were learned as the number of collocates per node word increased; the position of the node word did not affect learning, and synonymy had a negative effect on learning.

Additionally, few studies addressed issues concerning the enhancement of learners' writing skills. In this regard, Yeh, Liou, and $\mathrm{Li}$ (2007) carried out another research under the title of online synonym materials and concordancing for EFL college writing. They addressed overused adjectives by non-native speaking learners by aid of a bilingual collocation concordance; TANGO. The findings showed that, not only they improved in the immediate posttest, but also students' word knowledge for synonym use was retained as measured two months later in the delayed posttest. Moreover, in the post-instruction writing task, students avoided using general adjectives, and tried to apply more specific items to improve their overall writing quality. Sun (2007) also examined the effects that the learner variables had on participants' perception of the online Scholarly Writing Template (SWT). The results of the study showed that the template had different effects on students' scholarly writing processes and use of strategy. Indeed, students held a positive attitude towards the scholarly writing template.

Besides, concordancers allow language learners to engage in learning more actively and to search for linguistic patterns by directly exploring computerized corpora and concordancers; in other words, concordancers can be used as the key tools in the data-driven learning (DDL) approach. By computer-based DDL approach, learners can search the corpora with the help of a concordancer. In Iran, Tabriz, Jafarpour, and Koosha (2007) studied concordancing materials presented through data-driven learning approach and the findings showed that the data-driven approach is highly effective in the teaching and learning collocation of prepositions. Another study in Taiwan explored the DDL approach using concordance compiling software in teaching of J. K. Rowling's uses of the preposition in Harry Potter and the Philosopher's Stone by Lee (2009). The results pointed out that data-driven learning is helpful for students both in preparing for their exams and also for their general English acquisition.

In 2011, Chen undertook a research to determine if the new tool, WebCollocate, which is based on a large part of speech-tagged Gutenberg corpus could promote the DDL approach and facilitate the searching of collocations. The results indicated that the students who used the WebCollocate tool found more proper English collocates. And Thanh (2010), in Netherland, designed a survey to examine the effect of concordancing and scaffolding in developing learners' knowledge of lexical collocations. This study revealed that scaffolding did not make a significant difference in terms of the students' ability to identify (mis)collocations but concordancing produced significant effects on the subjects' overall performance in lexical collocation. 
Furthermore, in the field of translation, bilingual concordancers are the most widely used computer-assisted translation tools amongst translators. Bourdaillet et al. (2011) studied the improvement of the commercial bilingual concordance; TransSearch, in order to embed a word alignment feature. The results obtained through the use of a large translation memory consisting of 8.3 million sentence pairs were verified by human evaluation. Most of the above-mentioned studies have been done with different ESL or EFL learners at different levels of proficiency. Holec (1990) and Hadley (2002) claimed that concordancing might be relevant to advanced learners only as those of lower levels do not have enough linguistic resources and analytical skills to cope with authentic data. In this regard, this study aims to introduce learners who are at the same level of proficiency and in a homogenous class as intermediate level.

On the other hand, the studies show that concordancing-based treatments could be beneficial for English learning. Although, other studies have examined the effects of concordancing on various aspects of language learning, yet few previous studies have examined the impact of concordancing on the learning of reading skill. Therefore, it may be beneficial to design concordance-based materials with the aim of developing learners' reading skills through concordance-based extensive reading. Using different authentic stories instead of working on one literary text will encourage learners to be involved with different characters and genres and will possibly make a more optimum use of concordancer searches. In other words, learning can be driven by authentic language data (Johns 1991a; Johns 1991b). Since a few studies have been carried out to address the proficiency of reading skill by the aid of computer-based program, concordancer, the present study seeks to explore the impact of computer-assisted extensive reading instruction on EFL learners' reading comprehension.

\section{Methodology}

\subsection{Participants}

This study was conducted with nine female EFL learners in an English institute. The participants' age ranged from 20 to 30 years old with the mean age of 27.1 years old. The nine participants of this study served as both experimental group and control group.

\subsection{Instruments/Materials}

For the purpose of the present study, the following instruments were used:

Oxford Placement Test (OPT): The first instrument used in this study was Quick Placement Test (version 1) published by Oxford University Press to measure general proficiency of the participants and to homogenate the learners in terms of their level of proficiency.

Reading Comprehension Test: The second instrument was a multiple-choice reading comprehension test consisting of a passage that was administered prior to experimental and control phases of the study. The purpose was to trace all possible changes in EFL learners' reading comprehension ability. The reading comprehension posttest was given on the last day of instruction in order to probe their progress and the same procedure was followed as in the pretest. The test was piloted with a group of intermediate EFL learners. The content validity of the tests was ensured first, since they were piloted before. Based on the readability statistics, comprehension test was at intermediate level measured according to seven popular readability formulas that the researchers have mostly used (see http://www.readabilityformulas.com).

Progress Tests: In order to compare the progress of the participating EFL learners' reading skill, they were given a multiple-choice comprehension test every other session. The reading tests are graded tests and available freely on http://www.englishforeveryone.org. In spite of being graded, the readability of the passages was measured through the free tools available at http://www.readabilityformulas.com.

Instructional Materials: Since one of the key factors of ER is selecting the texts which can motivate learners, 
The impact of using concordancer on EFL learners' reading comprehension

using authentic materials in the instruction of EFL learners can possibly motivate and make them open to language input when their emotions, feelings, and attitudes are most engaged (Tomlinson, 1986). Considering this, learners' motivation increases when they are interested in what they are reading. In fact, before administrating the treatment, the genre of texts was consulted with the participating EFL learners. The necessary materials for the study were several authentic stories which were written by famous authors such as 'Eleven' by Sandra Cisneros, 'The Bracelet' by Yoshiko Uchida, 'A secret for two' by Quentin Reynolds and so on. The readability of the texts was determined first so that texts are of similar level of difficulty. For the control group the materials were prepared in hard copy and the soft copy (text format) was given to the experimental group. Initial piloting showed that learners were daunted by the difficulty of the authentic texts. This mode of learning was new to many students, because all of them were studying simplified or instructional textbooks in different institutes. Rigg (1991) and Widdowson (1979) noted that simplified texts offer insufficient exposure to unknown words, tedious rewriting, highly manipulated syntax, and distortions of pragmatic use. For this reason, using authentic texts of substantial length may contain enough repetitions of words and may provide more relevant results.

Concordancer: In order to administer the treatment in experimental group, a concordancer was searched. Among the concordancers; AntConcwas was chosen due to the easiness and accessibility of this program in the context of Iran and for EFL learners in particular. AntConc is a freeware concordance program that can be run simply by double-clicking and it does not need to be installed. This concordancer was developed by Professor Laurence Anthony; Director of the Centre for English Language Education, Waseda University (Japan).

\subsection{Procedure}

This study was conducted for 18 weeks from August to November 2012. Initially, the placement test was given to the participants to make certain that the participants were at the intermediate level of proficiency. Then, in the first session of the control phase of the study, the learners were given the comprehension test. Both experimental and control groups had similar curriculum, materials and instructor. Moreover, both classes were instructed for eighteen 90-minute sessions. Each day the students were assigned one story to read at home. Control group was instructed traditionally. The instruction heavily relied on annotations, the texts and dictionaries without specific teaching aids and at the end of the class, the participating EFL learners were engaged in a twenty-minute discussion.

The rationale of this component was that discussing a text with others gave them an opportunity to exchange their points of view. One session before treatment was administrated; the participants learned how to work with AntConc concordancer. Systematically, the possibilities of the program were explained for them and some exercises were conducted for more practices and understanding. In addition, in the first session of the experimental phase of the study, a pre-test was administrated to assess the participants' current level of reading comprehension skill. On the other hand, experimental group was exposed to computer-assisted language learning (CALL) classrooms and utilized the concordancer to explore different aspects of language and analyze them in various contexts. This also provided an opportunity for the learners to be actively involved and fully engaged in reading a text. The necessary materials for the study were several authentic stories which were written by famous authors.

For the control group the materials were prepared in hard copy and soft copy (text format) for experimental group respectively. It was intended for learners' independent self-study. The readability of the texts was set at a level that students were expected to attain at the end of the study. The order of the texts was from easy to difficult levels (Connelly, 1997) from 4 to 6 with a mean of 5. In order to consider text readability, the multiple choice comprehension tests in the present study were slightly more difficult than the texts that the students read in classes. At the end of the course, a post-test was employed for both groups to evaluate the improvement in their reading comprehension skill. Ultimately, when the required data was collected, the results of the pretest and posttest were compared to determine whether the integrating of the concordancer would help enhancing the 
Ashtiani, P. \& Tahriri, A.

participating learners' reading comprehension ability.

\section{Findings}

To answer the aforementioned research question, the results of the tests are given to explore the impact of learners' use of concordancer on reading skill. First, how learners performed in the pre-test, post-test and progress test was investigated. Due to the small sample size of the subjects $(\mathrm{N}=9)$, the statistical nonparametric method, the Wilcoxon Signed Rank Sum (Keller \& Warrack, 2002), was employed to analyze the test results. Comparisons were made to see if there were significant differences between (a) total scores of the pretest and the posttest of control group (see Table 1), and (b) total scores of the pretest and the posttest of experimental group (see Table 2), (c) total scores of the progress tests in control and experimental groups (see Table 3), and (d) the total scores of the posttest in both control and experimental groups (see Table 4).

Table 1

Comparison of pre-test and post-test scores for control group

\begin{tabular}{lllrrrr}
\hline \multicolumn{1}{c}{ Items } & & $n$ & $\begin{array}{c}\text { Mean } \\
\text { ranks }\end{array}$ & $\begin{array}{c}\text { Sum of } \\
\text { ranks }\end{array}$ & \multicolumn{1}{c}{$\begin{array}{c}\text { Z } \\
\text { score }\end{array}$} & $\begin{array}{l}\text { Asymp.sig. } \\
\text { (two-tailed) }\end{array}$ \\
\hline Pretest and posttest of control group & Negative ranks & $2^{\mathrm{a}}$ & 1.50 & 3.00 & $-1.863^{\mathrm{a}}$ & 0.063 (NS) \\
& Positive ranks & $5^{\mathrm{b}}$ & 5.00 & 25.00 & & \\
& Ties & $2^{\mathrm{c}}$ & & & & \\
& Total & 9 & & & & \\
\hline
\end{tabular}

Note. NS=Not significant

Table 2

Comparison of pre-test and post-test scores for experimental group

\begin{tabular}{lllrrrr}
\hline \multicolumn{1}{c}{ Items } & & $n$ & $\begin{array}{c}\text { Mean } \\
\text { ranks }\end{array}$ & $\begin{array}{c}\text { Sum of } \\
\text { ranks }\end{array}$ & $\begin{array}{c}\text { Z } \\
\text { score }\end{array}$ & $\begin{array}{c}\text { Asymp.sig. } \\
\text { (two-tailed) }\end{array}$ \\
\hline Pretest and posttest of experimental & Negative ranks & $7^{\mathrm{a}}$ & 4.50 & 31.50 & $-1.897^{\mathrm{a}}$ & $0.058(\mathrm{NS})$ \\
group & Positive ranks & $1^{\mathrm{b}}$ & 4.50 & 4.50 & & \\
& Ties & $1^{\mathrm{c}}$ & & & & \\
& Total & 9 & & & & \\
\hline
\end{tabular}

Note. $\mathrm{NS}=$ Not significant

Table 3

Comparison of progress tests scores for control and experimental group

\begin{tabular}{lllllll}
\hline \multicolumn{1}{c}{ Items } & & $n$ & $\begin{array}{c}\text { Mean } \\
\text { ranks }\end{array}$ & $\begin{array}{c}\text { Sum of } \\
\text { ranks }\end{array}$ & $\begin{array}{c}\text { Z } \\
\text { score }\end{array}$ & $\begin{array}{c}\text { Asymp.sig. } \\
\text { (two-tailed) }\end{array}$ \\
\hline Progress tests of control and & Negative ranks & $4^{\mathrm{a}}$ & 3.00 & 12.00 & $-0.324^{\mathrm{a}}$ & 0.746 (NS) \\
experimental groups & Positive ranks & $2^{\mathrm{b}}$ & 4.50 & 9.00 & & \\
& Ties & $3^{\mathrm{c}}$ & & & & \\
& Total & 9 & & & & \\
& & & & & & \\
& & &
\end{tabular}

Note. $\mathrm{NS}=$ Not significant

\section{Discussions}

As the tables indicate, no significant differences were found in the comparison between (a, Table 1) and (c, Table 3). Considering (b, Table 2), although the concordance-based pre-test and post-test were not significantly different in experimental group, it was as close as one can get to the significance level $(p=0.058)$ That is, the result showed slight improvement and to some extent, the influence of the treatment on the experimental group. In addition, it can be concluded the use of concordancer was helpful with reading comprehension. However, the 
The impact of using concordancer on EFL learners' reading comprehension

total score of the posttest in experimental group was significantly higher than the posttest in control group ( $p=0.042$ ). Hence, the positive results indicate that learners' reading skill increased significantly in working with computer-assisted program, concordancer. The answer to research question, therefore, is that the concordancer did enhance learners' reading skill.

Table 4

Comparison of post-tests scores for control and experimental groups

\begin{tabular}{lllrrrc}
\hline \multicolumn{1}{c}{ Items } & & $n$ & $\begin{array}{c}\text { Mean } \\
\text { ranks }\end{array}$ & $\begin{array}{c}\text { Sum of } \\
\text { ranks }\end{array}$ & $\begin{array}{c}\text { Z } \\
\text { score }\end{array}$ & $\begin{array}{c}\text { Asymp.sig. } \\
\text { (two-tailed) }\end{array}$ \\
\hline Posttests of control and experimental & Negative ranks & $7^{\mathrm{a}}$ & 4.64 & 32.50 & $-2.035^{\mathrm{a}}$ & $0.042^{*}$ \\
groups & Positive ranks & $1^{\mathrm{b}}$ & 3.50 & 3.50 & & \\
& Ties & $1^{\mathrm{c}}$ & & & & \\
& Total & 9 & & & & \\
\hline
\end{tabular}

Note. ${ }^{*} p<0.05$

On the one hand, most of the studies conducted concerning concordancing under the topic of skills and subskills, revealed significant improvement amongst learners in concordancing sessions. And the results of surveys reported that concordancing causes learners to outperform in English learning skills and promote independent and group learning (e.g., Cobb, 1997, 1999; Sun, 1999; Todd, 2001). Additionally, in order to learn about learners' feedback, some studies investigated the learner's attitude toward concordancing which found the learners' positive view (e.g., Lee \& Liou, 2003). On the other hand, the current study similarly suggested that concordancing could be an effective tool for language learning.

The current study investigated whether using computer-aided program; concordance, could increase EFL learners' reading comprehension. Nine EFL learners participated in the present study. The major findings indicate that students made significant improvement in their reading skill and their performance in the use of concordancer. It was also found, from the comparison of the pretest and posttest in experimental group, that the participants improved their overall reading proficiency. On average, learners' feedback showed that they did benefit from concordancing learning though it was somewhat difficult and time-consuming. On the other hand, the study suggested that an eclectic approach that implements concordancing and other traditional instructional methods may help learners better than the approach that relies on a single dominant teaching method.

The following limitations are noted for this study: The participating sample group represents a small percentage of the overall number of EFL learners. Therefore, the generalizability of the findings may be limited. As a consequence of the limited amount and the small size of corpora, it was attempted to provide the participating EFL learners with authentic short stories instead of simplified ones according to the readability of intermediate level. As the delimitations of the study, since the selection of both genders is a problematic issue in the context of Iranian institutes, the gender was not taken into consideration as a moderator variable and as such, female EFL learners were taken into account. In addition, the level of the participating EFL learners was limited to the intermediate level.

\section{Conclusion}

In light of the findings, some pedagogical implications can be drawn for EFL teachers and researchers. Concordancer could be utilized to facilitate learning English since it offers appropriate setting for a particular language skill. Therefore, learners could benefit from using words or phrases in context. Additionally, it can serve as a consulting tool for learners' self-instruction to search the proper examples. Further, learners can be encouraged to check desired components of language and then be motivated and feel more confident about the concordancing procedure for instruction. Besides, teachers can play the role of facilitators; they can design proper materials with clear goals for students or consider designing other types of in-class activities to search for 
Ashtiani, P. \& Tahriri, A.

certain linguistic features by making use of the concordancer in order to enhance language learning, that is, with careful planning and by prompting or providing patterns or hints which can direct learners' attention to important points and can help learners probe into the contextual language units in the concordancers. Subsequently, the learners should be asked to discuss their finding patterns from concordancers in class for clarification.

While technology is infused into a traditional curriculum and concordancing is to be incorporated into the EFL curriculum, it takes time for both learners and teachers to become accustomed to it; more guidance should be offered by teachers and further studies should be carried out. Furthermore, it would be worth examining if there are subject variables, motivation or learners' attitudes which may impact the effectiveness of one over another. Moreover, due to limited access to participants, the current study was conducted within small size. It could be recommended that future research be conducted with larger sample size and with different genders.

\section{References:}

Biber, D., Conrad, S., \& Reppen, R. (1998). Corpus linguistics: Investigating language structure and use. Cambridge: Cambridge University Press. http://dx.doi.org/10.1017/CBO9780511804489

Block, C. C., \& Pressley, M. (2002). Comprehension instruction. New York: Guilford.

Bloom, B. S., Englehart, T., Furst, E., Hill, W., \& Krathwohl, D. (1956). A taxonomy of educational objectives(Handbook 1): Cognitive domain. New York: David McKay.

Bourdaillet, J., Huet, S., Langlais, P., \& Lapalme, G. (2011). Trans-search: From a bilingual concordancer to a translation finder. Springer Science and Business Media B.V., 24, 241-271.

Brown, H. D. (2001). Teaching by principles: An interactive approach to language pedagogy ( $2^{\text {nd }}$ ed.). London: Longman.

Burns, A. (2003). Reading practices: From outside to inside the classroom. TESOL Journal, 12(3), 18-23.

Chan, T. P., \& Liou, H. C. (2005). Effects of web-based concordancing instruction on EFL students' learning of verb-noun collocations. Computer Assisted Language Learning, 18(3), 231-251. http://dx.doi.org/10.1080/09588220500185769

Chen, H. (2000). Developing a web concordancer for English as foreign language learners. Proceedings of ICCE/ICCAI 2000 Conference (pp. 340-341), Taiwan.

Chen, H. (2011). Developing and evaluating a web-based collocation retrieval tool for EFL students and teachers. Computer Assisted Language Learning, 24(1), 59-76. http://dx.doi.org/10.1080/09588221.2010.526945

Church, K., Gale, W., Hanks, P., \& Hindle, D. (1991). Using statistics in lexical analysis. In U. Zernik, (ed.) Lexical acquisition: Exploiting on-line resources to build a lexicon (pp. 115-164). Hillsdale, New Jersey: Lawrence Erlbaum Associates.

Cobb, T. (1997). Is there any measurable learning from hands-on concordancing? System, 25(3), 301-315. http://dx.doi.org/10.1016/S0346-251X(97)00024-9

Cobb, T. (1999) Applying constructivism: A test for the learner-as-scientist. Educational Technology Research and Development, 47(3), 15-31. http://dx.doi.org/10.1007/BF02299631

Connelly, M. (1997). Using C-test in English with post-graduate students. English for Specific Purposes, 16, 139-150. http://dx.doi.org/10.1016/S0889-4906(96)00018-X

Conrad, B., \& Rautenhaus, H. (1994). Innovations in teachers' education: Using the concordancer as a means for students at university and at school level. Paper presented at the Meeting of EUROCALL, Karisruhe, Germany.

Conrad, S. M. (1999). The importance of corpus-based research for language teachers. System, 27(1), 1-18. http://dx.doi.org/10.1016/S0346-251X(98)00046-3

Flowerdew, J. (1993). Concordancing as a tool in course design. System, 21(2), 231-244. http://dx.doi.org/10.1016/0346-251X(93)90044-H

Gabel, S. (2001). Over-indulgence and under-representation in interlanguage: reflections on the utilization of concordancers in self-directed foreign language learning. Computer Assisted Language Learning, 14 (3 \& 4), 269-288. http://dx.doi.org/10.1076/call.14.3.269.5792 
The impact of using concordancer on EFL learners' reading comprehension

Granger, S. (1998). Prefabricated patterns in advanced EFL writing: Collocations and formulae. In A. P. Cowie (Ed.) Phraseology: Theory, analysis and applications (pp. 145-160). Oxford: Oxford University Press.

Green, J. M. \& Oxford, R. (1995). A closer look at learning strategies, language proficiency and gender. TESOL Quarterly, 29, 261-297. http://dx.doi.org/10.2307/3587625

Hadley, G. (2000). Sensing the winds of change: An introduction to data-driven learning. RELC Journal, 33(2), 99-124. http://dx.doi.org/10.1177/003368820203300205

Hadley, G. (2002). An introduction to data-driven learning. RELC Journal, 33(2), 99-124. http://dx.doi.org/10.1177/003368820203300205

Haynes, M. (1983). Patterns and perils of guessing in second language reading. (ERIC Document Service Reproduction Number ED275149)

Holec, H. (1990). Does documents authentiques, pour quoi faire? Mélanges pédagogiques, 20, 65-74.

Horst, M., Cobb, T., \& Nicolae, I. (2005). Expanding academic vocabulary with an interactive online database. Language Learning \& Technology, 9(2), 90-110. Retrieved January 9, 2013, from http://lit.msu.edu/vol9num2/horst/default.html

Huckin, T., Hayne, S. M., \& Coday, J. (1991). Second language reading and vocabulary learning. Ablex, Norwood, NJ.

Ilse, W. R. (1991). Concordancing in vocational training. ELR Journal, 4, 103-113.

Lee, H. C. (2009). In defense of concordancing: An application of data-driven learning in Taiwan. Retrieved February 15, 2012, from http://www.sciencedirect.com/science/article/pii/S187704281100139X

Jafarpour, A., \& Koosha, M. (2007). Data-driven learning and teaching collocation of prepositions: The case of Iranian EFL students. Journal of Faculty of Letters and Humanities, 49, 1-29.

Johns, T. (1988). Whence and whither classroom concordancing? In T. Bongaerts et al. (Eds.), Computer applications in language learning. Dordrecht: Foris.

Johns, T. (1991a). From printout to handout: Grammar and vocabulary teaching in the context of data-driven learning. In T. Johns, \& P. King (Eds.), Classroom concordancing (pp. 27-45). Birmingham: University of Birmingham.

Johns, T. (1991b). Should you be persuaded: Two samples of data-driven learning. English Language Research Journal, 4, 1-13.

Johns, T. (1994). From printout to handout: Grammar and vocabulary teaching in the context of data-driven learning. In T. Odlin (Ed.), Perspectives on pedagogical grammar (pp. 293-313). New York: Cambridge University Press.

Johns, T. (1997). Contexts: The background, development, and trialling of a concordance based CALL program. In A. Wichmann, S. Fligelstone, T. McEnery, \& G. Knowles (Eds.), Teaching and language corpora (pp. 100-115). London: Longman.

Johnson, D. W., Johnson, R. T., \& Stanne, M. B. (2000). Cooperative learning methods: A meta-analysis. Retrieved December 17, 2012, from http://www.cooperation.org/pages/cl-methods.html

Keller, G., \& Warrack, B. (2002). Statistics for management and economics. Belmont, CA: Duxbury Press. Krashen, S. (1993).The power of reading. Englewood: Libraries Unlimited.

Krashen, S. D. (1981). Second language acquisition and second language learning. Oxford: Pergamon.

Laufer, B., \& Sim, D. (1985). Taking the easy way out: Non-use and misuse of clues in EFL reading. English Teaching Forum, 2, 7-10.

Lee, C. Y., \& Liou, H. C. (2003). A study of using web concordancing for English vocabulary learning in a Taiwanese high school context. English Teaching \& Learning, 27(3), 35-56.

Nation, I. S. P. (2001). Learning vocabulary in another language. Cambridge: Cambridge University Press. http://dx.doi.org/10.1017/CBO9781139524759

Nuraihan, M. D., \& Husin, Z. (2004). Developing critical thinking skills in computer-aided extended reading classes. British Journal of Educational Technology, 35(4), 477-487. http://dx.doi.org/10.1111/j.0007-1013.2004.00405.x

Rigg, P. (1991). Whole language in TESOL. TESOL Quarterly, 25(3), 520-540. http://dx.doi.org/10.2307/3586982 
Ashtiani, P. \& Tahriri, A.

Romiszowski, A. (1996). Web-based distance learning and teaching: Revolutionary invention or reaction to necessity? In B. Khan (ed.), Web-based instruction (pp. 25-37). Englewood Cliffs, NJ. Educational Technology Publications.

Smadja, F. A., \& McKewon, K. R. (1990). Automatically extracting and representing collocations for language generation. Proceedings of the 28th Annual Meeting of the Association for Computational Linguistics (pp. 252-259), Pittsburgh, PA, USA. p://dx.doi.org/10.3115/981823.981855

Someya, Y. (2000). Online business letter corpus KWIC concordancer and an experiment in data-driven learning/writing. Paper presented at the 3rd Association for Business Communication International Conference, Dashisha University, Kyoto, Japan. Retrieved February 15, 2012 from http://www.kamakuranet.ne.jp/ someya/DDW_Report.html

St. John, E. (2001). A case for using a parallel corpus and concordancer for beginners of a foreign language. Language Learning \& Technology, 5(3), 185-203.

Steven,V. (1991) Classroom concordancing: Vocabulary materials derived from relevant authentic text. English for Specific Purpose 10, 1, 35-46. http://dx.doi.org/10.1016/0889-4906(91)90014-N

Sun, Y. C. (1999). Web-based concordancing: Challenges and opportunities for English language teaching. Proceedings for the English International Symposium on English Teaching (pp. 517-526). Taipei: Crane.

Sun, Y. C. (2003). Extensive reading online: An overview and evaluation. Journal of Computer Assisted Learning, 19, 438-446. http://dx.doi.org/10.1046/i.0266-4909.2003.00048.x

Sun, Y. C. (2007). Learner perceptions of a concordancing tool for academic writing. Computer Assisted Language Learning, 20(4), 323-343. http://dx.doi.org/10.1080/09588220701745791

Sun, Y. C., \& Wang, L.Y. (2003). Concordancers in the EFL classroom: Cognitive approaches and collocation difficulty. Computer Assisted Language Learning, 16(1), 83-95. http://dx.doi.org/10.1076/call.16.1.83.15528

Thanh, H. L. (2010). Learning lexical collocations with concordancing and scaffolding. Retrieved February 15 , 2012, from http://scripties.let.eldoc.ub.rug.nl/FILES/root/Master/DoorstroomMasters/ToegepasteTaalwetens/2010L e/MA_1938851_T_H_Le.pdf

Todd, R.W. (2001). Induction from self-selected concordances and self-correction. System, 29(1), 91-102. http://dx.doi.org/10.1016/S0346-251X(00)00047-6

Tomlinson, B. (1986). Openings. London: Lingual House.

Turnbull, J., \& Burston, J. (1998). Towards independent concordance work for students: Lessons from a case study. On-Call, 12(2), 10-21.

Webb, S., \& Kagimoto, E. (2009). Learning collocations: Do the number of collocates, position of the node word, and synonymy affect learning? Applied Linguistics, 32(3), 259-276. http://dx.doi.org/10.1093/applin/amq051

Widdowson, H. G. (1979). Explorations in applied linguistics. Oxford: Oxford University Press.

Yeh, Y., Liou, H. C., \& Li, Y. H. (2007). Online synonym materials and concordancing for EFL college writing. Computer Assisted Language Learning, 20(2), 131-152. http://dx.doi.org/10.1080/09588220701331451

Zahar, R., Cobb, T., \& Spada, N. (2001). Acquiring vocabulary through reading: Effects of frequency and contextual richness. Canadian Modern Language Review, 57(4), 541-572. http://dx.doi.org/10.3138/cmlr.57.4.541 